\title{
Assessment of the Waterway Variant at the Design Stage in Multiple-criteria Approach
}

\author{
K. Formela \\ Gdynia Maritime University, Gdynia, Poland
}

\begin{abstract}
The assessment of navigational safety for various variants of waterways, due to the multiplicity of entities involved in the decision-making process, is a complex and difficult task. Multiple methodologies can be used to select and arrange projects. A review of the literature leads to the conclusion that the CBA (Cost Benefit Analysis) and MCDA (Multi-Criteria Decision-Making Analysis) methodologies are most often used. The article presents, the general characteristics of the proposed multi-criteria methodology assessment of waterway at the design stage.
\end{abstract}

\section{INTRODUCTION}

Due to the simultaneous increase in the operational parameters of ships and the specialization in handling units specific to a given port, their operation for many ports becomes more difficult (Matczak M. 2017, Krośnicka K. 2016, Kaizer A. 2013). Therefore, the selection of the appropriate variant of the designed waterway is currently the subject of interest of port authorities, administration and their future users as an investment necessary to ensure the safety of these units and further development of the port (Gucma S. 2015).

There are many methods of detailed shipping safety risk assessment (D'Angremond K. 1998, Dhillon B.S. 2011, Rausand M. 2011), including the Polish method of dimensioning the width of the safe maneuvering area of waterways using the navigational risk models developed at the Maritime University in Szczecin (Gucma S. 2013). These methods, however, require detailed statistical or simulation studies, which are not always used when designing waterways or determining the conditions of their safe operation, or are used too generally.
In this paper, the author describes and analyzes how the concept of selecting a given variant of the designed waterway in terms of maritime traffic engineering is understood, which affects the efficiency and safety of ship traffic after the investment is completed.

\section{NAVIGATIONAL SAFETY ON WATERWAY}

Navigational safety can be defined in a number of ways (Formela K., Neumann T., Weintrit A. 2019). In terms of marine traffic engineering, a waterway is a restricted body of water, adapted and used for the movement of various types of marine vessels. Marine traffic engineering deals with the qualitative and quantitative description of ship traffic in restricted areas in terms of navigation safety (Gucma S. 2015).

The safety of navigation in relation to the sea route is the state of the maritime traffic engineering system related to accident-free routing of the ship in accordance with the purpose of its voyage, while maintaining the required traffic parameters (Gucma 
S. 2015). Therefore, it is a state of the system related to the accident-free passage of the ship by sea. The basic condition for navigation on sea waterways is the safety of navigation, understood as the safety of the ship and its surroundings during maneuvers in these waters in terms of the possibility of a navigational accident (an undesirable event causing damage and loss (Oltedal, H. A. (Ed.), Lutzhoft, M. (Ed.), 2018)

Factors that may cause accidents on waterways are their parameters (length, width, depth, clearance under bridge structures) and the presence of hydro technical structures on them, as they constitute a potential source of danger in the event of their malfunction or improper marking (Jerzyło P., Wawrzyńska A. 2018). Another factor that has a significant impact on the safety of navigation are the prevailing hydro meteorological conditions as well as the intensity and intensity of traffic in a given place and time. The basic hydro meteorological conditions include: water level, wind, currents, waves, temperature and precipitation. They cause unfavorable phenomena for shipping, which not only may limit navigation and shorten the shipping season, but may also contribute to the initiation of adverse events.

Based on this, it can be concluded that in order to ensure safe navigation by reducing the risk of vessel traffic on waterways, methods of safety and navigation risk assessment of should be used.

\section{METHODOLOGY OF NAVIGATIONAL SAFETY ASSESSMENT FOR VARIOUS VARIANTS OF THE WATERWAY}

In the process of maritime transport management, one of the main tasks within which many decisionmaking problems arise is its improvement through specific projects (Ministerstwo Transportu, Budownictwa I Gospodarki Morskiej 2013, Zak J. 2015). The selection of the proposed variants of waterways, or their ordering from the most desirable to the less important, requires an appropriate analysis using the selected methodology providing the appropriate tools (methods). The methodology of the analysis and the criteria related to it are strictly dependent on whether the analysis concerns the assessment of the maritime transport system in the present state or a project improving this system.

Several postulates have been formulated to propose a new general approach to the assessment of waterway projects at the design stage. The most important of them include:

- the possibility of a comprehensive assessment of variants / projects of various nature,

- the possibility of assessing variants / projects before their implementation, and above all, as a support for the discussion preceding the approval of the investor's budget,

- possibility of evaluating a large number of variants / projects of different nature

- the possibility of active participation of the decision-maker / interveners in the decisionmaking process,
- the possibility of using modern and currently available computational methods, tools and computer techniques.

The desired effect of this approach is the list which presents the considered projects in a ranking, from the project that has the best impact (has the highest usability) for navigational safety, to the project that has the lowest impact on achieving the goal.

The assessment of projects related to the design of variants of waterways is particularly difficult. The cause of the difficulties of this issue is due to in properly defined criteria, for each of the proposed elements of variants assessed quantitatively or qualitatively. As a rule, different types of assessment criteria are used to evaluate different types of waterways, which results primarily from their purpose and nature.

The basic measure of assessing variants of design solutions is the level of meeting the criteria specified by the decision-maker. In this study, the concept of decision maker means the investor who decides about the location of the investment and the final form of the elements of the waterway, characterized by specific technical and operational features. Despite the fact that some of these criteria are difficult to determine objectively (quantitatively), there is a need to find a synthetic measure of the technical and utility values of the facility. The right selection of criteria is as important as the correct assessment of the level of their fulfillment, both for the aforementioned investor, client and a potential user of the waterway.

The decision-makers approach is strongly influenced by the opinions and assessments of experts, including in particular maritime traffic engineers and experienced navigators. Such expert assessments are often the subject of navigational analyzes commissioned by the investor. Experts are expected to make assessments consistent with the current level of knowledge, reliable, objective and taking into account the specificity of a given decisionmaking situation. However, it is difficult to unequivocally define individual preferences, value system and expert motives.

The expert's preferences are largely dependent also on the point of view of the decision-maker for whom the analysis is prepared. Other preferences in terms of the technical and operational conditions of the facility will be accepted by the investor, client or user of the waterway.

In the proposed method, the following sequence of actions was adopted:

- establishing the criteria for evaluating variants,

- selection of a method for comparing and prioritizing decision variants,

- carrying out computational (simulation) tests,

- analysis of the obtained results,

- determining the ranking of variants,

- development of final conclusions.

The issue of setting criteria is a very specific and individual issue. It is concentrated in the questionnaire prepared by the author. Ultimately, the proposed methodology should allow for quick determination of the order of the various variants of the designed waterway under consideration. The 
conclusions from this analysis make it possible to confidently and consciously choose the variant that best meets the criteria specified in the survey. Figure 4.1 presents a general procedure for assessing decision variants under the proposed methodology.

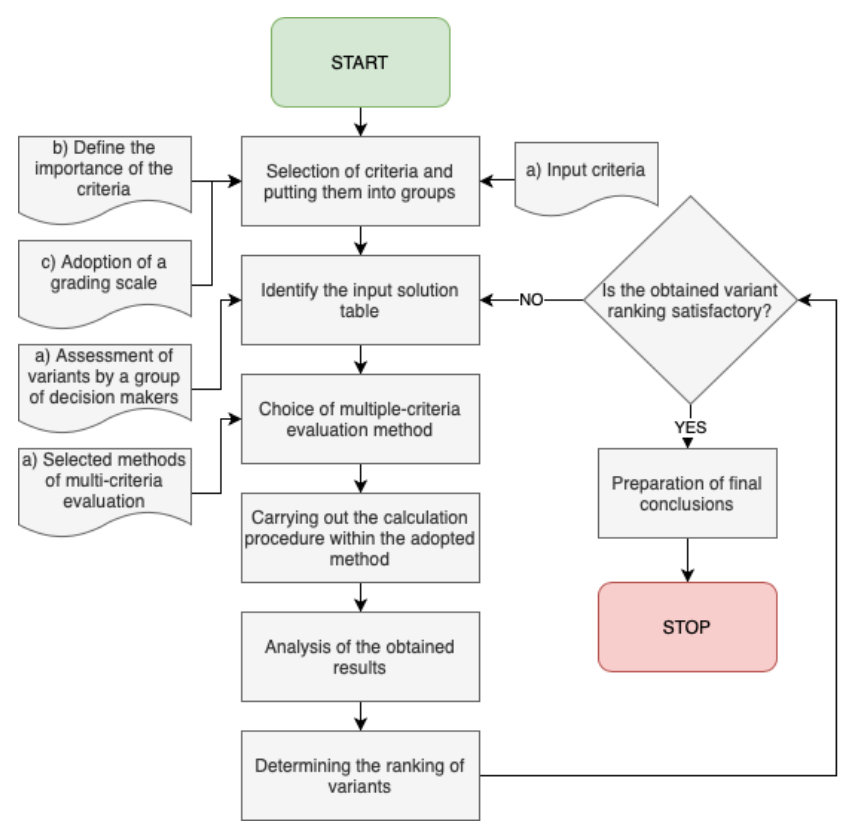

Figure 1 Scheme of procedure for the assessment of various variants of waterways in terms of multiple criteria.

As a result of the survey, it is possible to formulate and select a basic group of criteria and define their degrees of importance, due to the preferences specified by the respondents. A set of criteria, segregated into groups, their degrees of properties and preferences defined by decision-makers in relation to various variants of the designed waterway, constitute the starting point for the methodology of evaluation of solutions proposed by the author. Based on the research results obtained, it is possible to improve the hierarchy of the considered solutions and to select the best variant.

Performing the calculation procedure within the adopted method is possible on the basis of many different available methods, depending on the complexity scale of the decision problem under consideration (selection of the proposed variants of waterways).

When carrying out a calculations on the selection of a waterway variant, a comparative analysis of the criteria related to the safety of navigation in terms of maritime traffic engineering can be proposed. However, provided for the analysis, the criteria should be confronted with the relevant actual data from a specific location in relation to the planned variant

Many different methods are available for design process, including actual studies, studies with simulation tools, or a combination of these that have different capabilities, functions, and applications. The basic criteria for the classification of simulation methods used in the study of vessel traffic in limited areas include the time and type of ship model steering.
Taking into account the time during which the simulation takes place, these methods are divided into (Gucma S. 2015):

- real Time Simulation (RTS) methods,

- fast Time Simulation (FTS) methods.

The simulation methods in the aspect of ship traffic management are divided into (Gucma S. 2015):

- methods using autonomous models,

- methods using non-autonomous models.

The use of a simulation tool is able to provide realistic and accurate results as input for the study and evaluation of newly constructed waterway designs. The purpose of design, planning and evaluation simulations is to identify and reduce (quantitatively) the risk to the future user operating on a specific waterway. It also includes a (qualitative) assessment of the waterway system, technical specification and maneuvering aspects. Simulation studies offer a relatively low-cost method that helps provide solutions to waterway users in an effective and efficient manner (NRC, 1996).

Simulations can provide a high level of realism as long as the purpose of the simulation is consistent with the accuracy of the models. Hence, the accuracy of ship models, environments and related navigational aids, along with appropriate planning and configuration of simulated scenarios, should be carefully considered by the end user (NRC, 1996).

Before starting the research, it may be necessary to consult with representatives of the maritime administration, who have practical professional knowledge about the analyzed area.

The results of the tests are processed, which allows for aggregation and import of the collected criteria to the prepared sheet, in order to use them in the calculation procedure, analysis of results and drawing conclusions.

\section{CONCLUSIONS}

The proposed methodology for the multi-level, multicriteria assessment of waterways variants with different nature is based on the general methodology of solving multi-criteria decision problems.

As a result of the application of the multi-level methodology, multi-criteria assessment of variants / projects, a summary of waterway projects is obtained. Conclusions from this assessment allow for a safe and conscious choice of the variant that is closest to meet the criteria specified in the survey.

The choice of the waterway variant at the design stage is crucial for the future operation of waterways and ports, which is part of the research on maritime transport infrastructure.

\section{REFERENCES}

D'Angremond K., „Risk Assessment in port planning and operation including port approaches". 29th PIANC Navigation Congress, 1998. 
Dhillon B.S., „Transportation Systems Reliability and Safety", CRC Press Taylor \& Francis Group, New York, 2011.

Formela K. and Kaizer A., „The concept of modernization works related to the capability of handling e class container vessels in the Port of Gdynia", [in:] A. Weintrit \& T. Neumann (Eds): Marine Navigation and Safety of Sea Transportation: Maritime Transport \& Shipping. CRC Press, Taylor \& Francis Group., 2013.

Formela K., Neumann T., Weintrit A.: Overview of Definitions of Maritime Safety, Safety at Sea, Navigational Safety and Safety in General. TransNav, the International Journal on Marine Navigation and Safety of Sea Transportation, Vol. 13, No. 2, doi:10.12716/1001.13.02.03, pp. 285-290, 2019

Gucma S., Morskie drogi wodne. Projektowanie i eksploatacja w ujęciu iżynierii ruchu morskiego. Gdańsk: Fundacja Promocji Przemysłu Okrętowego i Gospodarki Morskiej, 2015.

Gucma S, Ślączka W., Zalewski P., Parametry torów wodnych i systemów nawigacyjnych wyznaczane przy wykorzystaniu kryteriów bezpieczeństwa nawigacji. Szczecin: Wydawnictwo Naukowe Akademii Morskiej w Szczecinie, 2013.
Jerzyło P. and Wawrzyńska A., „Identyfikacja czynników wpływających na bezpieczeńśtwo eksploatacji statku na śródlądowej drodze wodnej w Delcie Wisły", Prace Naukowe Politechniki Warszawskiej, 2018

Krośnicka K., Przestrzenne aspekty kształtowania i rozwoju morskich terminali kontenerowych. Gdańsk: Wydawnictwo Politechniki Gdańskiej, 2016.

Matczak M., Polskie porty morskie jako biegun rozwoju gospodarczego kraju i regionów lokalizacji. Gdynia: Rada Interesantów Portu Gdynia, 2017.

National Research Council (NRC), 1996. Simulated Voyages: Using Simulation Technology to Train and License Mariners. Washington, DC: The National Academies Press. https://doi.org/10.17226/5065.

Oltedal, H. A. (Ed.), Lutzhoft, M. (Ed.), Managing Maritime Safety. London: Routledge 2018\

Program rozwoju polskich portów morskich do roku 2020 (z perspektywą do 2030 roku). Warszawa: Ministerstwo Transportu, Budownictwa i Gospodarki Morskiej, 2013.

Rausand M., ",Risk Assessment. Theory, Methods and Applications", Wiley, New Jersey, 2011.

Żak J., Wielokryterialne wspomaganie decyzji w transporcie drogowym. Poznań: Politechnika Poznańska, 2005 